\title{
The Role of Megalin in the Transport of Gentamicin Across BeWo Cells, an In Vitro Model of the Human Placenta
}

\author{
Amal A. Akour, ${ }^{1}$ Mary Jayne Kennedy, ${ }^{1}$ and Phillip M. Gerk ${ }^{2,3}$
}

Received 18 November 2014; accepted 24 April 2015; published online 19 May 2015

\begin{abstract}
Aminoglycosides (AG) are known to readily cross the placenta, although the mechanisms responsible for placental transport have not been characterized. Megalin is expressed in human placenta, and it is reasonable to speculate, given its role in renal AG uptake, that it is similarly involved in placental transport. However, the role of megalin in placental AG uptake has not been established. An in vitro model to study megalin-mediated placental transport has also not been previously described. The objectives of this study, therefore, were to evaluate the human choriocarcinoma (BeWo) cell line as a model to study megalin-mediated placental transport and to assess the uptake kinetics of gentamicin, an AG antibiotic, using this in vitro model. BeWo cells were grown on Transwell ${ }^{\circledR}$ plates, and megalin expression and functional activity were assessed. Uptake of ${ }^{3} \mathrm{H}$-gentamicin was also evaluated in the presence and absence of megalin inhibitors. Expression of megalin protein and mRNA in BeWo cells were confirmed via immunoblot and qPCR analysis. Uptake of fluorescein isothiocyanate (FITC)-labeled bovine serum albumin (BSA) (a megalin substrate) was time-, concentration-, and temperature-dependent consistent with a transporter-mediated process. FITC-BSA uptake was also significantly reduced in the presence of unlabeled gentamicin (a megalin substrate) and sodium maleate (to induce megalin shedding) suggesting that megalin is functionally active in BeWo cells. Gentamicin uptake exhibited time and temperature dependence, saturability and Michaelis-Menten kinetics, all of which suggest a transporter-mediated process. Gentamicin uptake was also significantly reduced in the presence of the megalin inhibitors RAP and EDTA suggesting that megalin is likely involved in gentamicin uptake.
\end{abstract}

KEY WORDS: aminoglycosides; gentamicin; megalin; placenta; receptor-mediated endocytosis.

\section{INTRODUCTION}

Intra-amniotic infections (IAIs) are common complications of labor and delivery occurring in up to $10 \%$ of term

${ }^{1}$ Department of Pharmacotherapy and Outcomes Science, Virginia Commonwealth University, Richmond, Virginia, USA.

${ }^{2}$ Department of Pharmaceutics, School of Pharmacy, Virginia Commonwealth University, 410 N. 12th StreetPO Box 980533, Richmond, Virginia 23298-0533, USA.

${ }^{3}$ To whom correspondence should be addressed. (e-mail: pmgerk@vcu.edu)

\footnotetext{
ABBREVIATIONS: AGs, Aminoglycosides; ANOVA, Analysis of variance; DIDS, 4 4'-diisothiocyanostilbene-2,2'-disulfonic acid; DMEM, Dulbecco's modified Eagle medium; DMSO, Dimethyl sulfoxide; DPBS, Dulbecco's phosphate buffered saline; DPM, Disintegrations per minute; EDTA, Ethylenediaminetetraacetic acid; FITC, Fluorescein isothiocyanate; FITC-BSA, Fluorescein-labeled bovine serum albumin; HepG-2, Human hepatocellular carcinoma cells; HK-2, Human kidney cells type 2; IAI, Intra-amniotic infection; LCC-PK1, Lewis lung carcinoma porcine kidney cells; LSC, Liquid scintillation counter; MDCK, Madin-Darby canine kidney epithelial cells; NPPB, 5-Nitro-2(3-phenylpropylamino) benzoic acid; NTC, Non-template control samples; PBS, Phosphate buffered Saline; qPCR, Quantitative polymerase chain reaction; RAP, Receptor-associated protein; RME, Receptormediated endocytosis; RT, Reverse transcriptase enzyme; SDS, Sodium dodecyl sulfate; TEER, Transepithelial electrical resistance; VCU, Virginia Commonwealth University
}

and $25 \%$ of pre-term pregnancies (1-3). If inadequately treated, these infections can lead to serious complications for both the mother and the fetus. Aminoglycoside antibiotics (AGs) are part of the standard treatment regimen for documented and suspected IAIs (4) and are good candidates for intrapartum delivery because they readily cross the placenta and rapidly achieve bactericidal levels in the fetal serum (5-8). The clinical utility of these antibiotics is limited, however, by their tendency to accumulate in fetal renal tissue after maternal administration and achieve high and persistent levels, even after administration of a single dose. Given the known correlation between the rate and the extent of AG accumulation in renal tissue and susceptibility to nephrotoxicity (9), the fetus is particularly vulnerable to the nephrotoxic effects of maternally administered AGs. Persistence of AGs in renal tissues after birth may also increase susceptibility of the newborn to injury during early postnatal life when AGs are routinely administered to prevent or treat infections acquired in utero. Consequently, the need to achieve therapeutic AG levels in the fetal serum must be carefully balanced with the inherent risk of developmental nephrotoxicity.

Unlike ATP-binding cassette transporters and solute carriers, megalin is an endocytic receptor and is expressed on the apical surfaces of absorptive epithelia. Megalin is responsible for the uptake of AGs into renal proximal tubular epithelial cells, the physiologic site of AG induced renal injury (10). Pharmacologic blockade of the megalin receptor 
has been shown to limit renal accumulation of AGs and prevent nephrotoxicity in animal models (11). This strategy may be useful in preventing drug accumulation in the fetal kidney during intrapartum $\mathrm{AG}$ administration but only if placental drug transport remains unaltered by megalin receptor blockade. It is therefore important to understand the molecular mechanisms involved in placental AG transport so that targeted strategies to limit renal accumulation without compromising placental transport can be developed.

Data from previous maternal-fetal pharmacokinetic studies indicate that both passive diffusion and receptor-mediated transport are involved in the placental uptake of AGs (6-8). The administration of 40 and $80 \mathrm{mg}$ of intramuscular gentamicin during labor resulted in peak cord serum levels that were 34\% (12) and 42\% (13) of associated maternal blood concentrations within 1-2 h, respectively. In the first study (12), the peak maternal serum concentrations $(3.7 \pm 0.5 \mu \mathrm{g} / \mathrm{mL})$ were achieved after $30 \mathrm{~min}$ of administration, while the peak cord levels of $1.25 \mu \mathrm{g} / \mathrm{mL} \pm 0.15$ were achieved within 60-120 min. In the latter (13), the maternal serum peak level was $2 \mu \mathrm{g} / \mathrm{mL}$ while the cord levels were $\sim 0.8 \mu \mathrm{g}$ / $\mathrm{mL}$ and reached $90 \mathrm{~min}$ from administration. When gentamicin was administered as an intravascular infusion (80-mg loading dose, then infusion at a rate of $18.5 \mathrm{mg} / \mathrm{h})$, cord serum levels equal to $1.1 \mu \mathrm{g} / \mathrm{mL}$ were reached within the first $2 \mathrm{~h}(\sim 30 \%$ of the associated maternal serum level) (14). The same doses of gentamicin given prior to delivery achieved mean amniotic fluid concentrations of $(5.17 \mu \mathrm{g} / \mathrm{mL}) 8 \mathrm{~h}$ post administration. In a study comparing the level of gentamicin (dose was unreported) in maternal blood, cord blood, and placental membranes, gentamicin level was about four-fold higher in placental membranes than that in cord blood (maternal blood levels = $3.5 \mu \mathrm{g} / \mathrm{mL} \pm 1.0$; cord blood levels $=2.2 \mu \mathrm{g} / \mathrm{mL} \pm 1.0$; and placental levels $=13.9 \mu \mathrm{g} / \mathrm{mL} \pm 10)(8)$.

Expression of the megalin receptor has been previously demonstrated in human term placenta (15) and preterm placenta, and it is reasonable to speculate, given its role in renal AG uptake, that it is similarly involved in the placental uptake of AGs. However, the role of megalin in AG placental uptake has not been evaluated. An in vitro model to study megalin-mediated placental transport has also not been previously described. The objectives of this study, therefore, were to evaluate the human choriocarcinoma (BeWo) cell line as a model to study megalin-mediated placental transport and to assess the uptake kinetics of gentamicin, an AG antibiotic, using this in vitro model.

\section{METHODS}

\section{Establishment and Maintenance of Cell Lines}

Human Choriocarcinoma (BeWo) Cells. BeWo cells (b30 clone; obtained from Dr. Ken Audus, University of Kansas) were maintained by serial passages $(36-48)$ in $25-$ and $75-\mathrm{cm}^{2}$ Corning® plastic tissue culture flasks (Corning Inc., Corning, NY). Cells were fed using Dulbecco's modified Eagle medium (DMEM; Thermo Scientific, Rockford, IL) supplemented with $10 \%$ fetal bovine serum (FBS), 1\% L-glutamine, penicillinstreptomycin, and nonessential amino acids and incubated at $37^{\circ} \mathrm{C}$ in an atmosphere of $95 \%$ air and $5 \% \mathrm{CO}_{2}$. When confluent monolayers were formed, cells were sub-cultured by detachment with $0.05 \%$ trypsin-EDTA. Cells of passages $36-48$ were seeded at 150,000 cells/well in 12-well Transwell@ 3460 polyester plates ( $\mathrm{SA}=1.12 \mathrm{~cm}^{2}$; Corning Inc., Corning, NY). Transwell plates were selected based on previous studies in other cell lines, which demonstrated that a three-dimensional environment is required for expression of the megalin protein $(16,17)$. Medium was changed every other day, and confluence was achieved after 5-7 days (TEER 70-80. $\mathrm{cm}^{2}$ ).

Human Hepatocellular Carcinoma (HepG2) Cells. HepG2 cells were maintained by serial passages $(82-85)$ in $25-$ and $75-\mathrm{cm}^{2}$ Corning ${ }^{\circledR}$ plastic tissue culture flasks (Corning Inc., Corning, NY) and were used as a potential negative control (where there is no evidence of megalin expression and activity) $(10,18)$. Cells were fed using DMEM (Thermo Scientific, Rockford, IL) supplemented with $10 \% \mathrm{FBS}$ and $1 \%$ nonessential amino acids and incubated at $37^{\circ} \mathrm{C}$ in an atmosphere of $95 \%$ air and $5 \% \mathrm{CO}_{2}$. When confluent monolayers were formed, cells were sub-cultured by detachment with $0.05 \%$ trypsin-EDTA and seeded at 150,000 cells/well in 12-well Transwell® 3460 polyester plates $\left(\mathrm{SA}=1.12 \mathrm{~cm}^{2}\right.$; Corning Inc., Corning, NY). Media was changed every other day, and confluence was achieved after 3-4 days (TEER 40-50. . ${ }^{2}$ ).

Madin-Darby Canine Kidney (MDCK) Cells. ATCCtype MDCK cells were maintained by serial passages (22 to $25)$ in $25-$ and $75-\mathrm{cm}^{2}$ Corning plastic tissue culture flasks (Corning Inc., Corning, NY) and used as the positive control (19). Cells were fed using DMEM (Thermo Scientific, Rockford, IL) supplemented with 10\% FBS, $1 \%$ nonessential amino acids, and penicillin-streptomycin and incubated at $37^{\circ} \mathrm{C}$ in an atmosphere of $95 \%$ air and $5 \% \mathrm{CO}_{2}$. When confluent monolayers were formed, cells were sub-cultured by detachment with $0.05 \%$ trypsin-EDTA and seeded at 150,000 cells/well in 12 -well Transwell@ 3460 polyester plates (SA=1.12 cm $\mathrm{cm}^{2}$ Corning Inc., Corning, NY). Media was changed every other day, and confluence was achieved within 3-4 days (TEER 280-310 .cm²).

\section{Megalin Protein and mRNA Expression}

Immunoblot Analysis. BeWo cells (passages 36-37) were seeded on 6-well Transwell@ 3450 plates $\left(200,000\right.$ cells $\left./ \mathrm{cm}^{2}\right)$ and harvested when confluence was reached (day 5). Growth media was removed and cells were washed twice with ice-cold PBS. Approximately $200-300 \mu \mathrm{L}$ of ice-cold lysis buffer $(150 \mathrm{mM} \mathrm{NaCl}$, $1 \mathrm{mM}$ EDTA and $20 \mathrm{mM}$ of Tris, $1 \%$ Triton X-100) containing 1:100 Halt@ Protease inhibitor (Thermo Scientific, Rockford, IL) at $\mathrm{pH}=7.4$ was then added to each well. Cells were incubated on ice with the lysis buffer for $30 \mathrm{~min}$ and were subsequently scraped out of the plate and transferred to a pre-cooled centrifuge tube. The suspension was centrifuged at 12,000 rpm for $20 \mathrm{~min}$ and the resulting supernatant used for analysis.

Protein concentrations in the supernatant were determined using the BCA protein assay kit (Thermo Scientific, Rockford, IL) with bovine serum albumin (BSA) as a standard. Approximately 100-200 $\mu \mathrm{g}$ of membrane protein was loaded onto a 4-12\% polyacrylamide BioRad® Tris-glycine denaturing gel (BioRad®, Hercules, CA) and electrophoresed at $100 \mathrm{~V}$ for $45 \mathrm{~min}$. Separated proteins were subsequently fixed with $50 \%$ isopropyl alcohol and $12 \%$ acetic acid for $15 \mathrm{~min}$ at room temperature, and after fixation, the gel was washed with ultrapure water. Binding of the primary (rabbit anti-human megalin, 
1:200; mouse anti-human $\beta$-actin, 1:2000, Sigma Aldrich, St. Louis, MO) and secondary (goat anti-mouse Alexa Fluor 680, 1:5000, goat anti-rabbit IR Dye 800, 1:2000; Li-Cor ${ }^{\circledR}$, Lincoln, $\mathrm{NE}$ ) antibodies was performed in $5 \% \mathrm{BSA}$ at $4^{\circ} \mathrm{C}$ overnight and at room temperature for $1 \mathrm{~h}$ in the dark, respectively. The resulting fluorescent complexes were detected, and the band visualized using the Odyssey Infrared Imaging System (LiCor ${ }^{\circledR}$, Lincoln, NE). Mouse kidney tissue and liver tissue (from normal adult female mice kindly obtained from Dr. Matthew Beckman through the VCU Transgenic Mouse Facility) were used as positive and negative controls, respectively.

RNA Isolation and Quantitative PCR (qPCR). Total RNA was isolated according to the Trizol® isolation protocol (Invitrogen, Carlsbad, CA). Trizol ${ }^{\circledR}$ lysates of MDCK and HepG-2 cells grown on 12-well Transwell ${ }^{\circledR}$ plates were used as positive and negative controls, respectively. Briefly, cells were prewashed twice with ice-cold PBS, and $1 \mathrm{ml}$ of Trizol® was added to each well at room temperature. The resulting cell lysate was then transferred to a centrifuge tube for further isolation. Total RNA $(2.5 \mu \mathrm{g})$ was digested by DNAse I (Promega, Madison, WI), and the total concentration of mRNA was measured using the Nanodrop ${ }^{\circledR}$ 2000c (Thermo Scientific, Rockford, IL). Purity of the RNA preparation was assessed using the 260/280 nm ratio. Samples with ratios between 1.7 and 2.1 were subjected to reverse transcription in a $20-\mu 1$ reaction mixture (Goscript ${ }^{\circledR}$ Promega Reverse Transcription System; Madison, WI) containing the following: reverse transcriptase enzyme (RT), $25 \mathrm{mM} \mathrm{Mg}(\mathrm{Cl})_{2}$, $5 \mathrm{X}$ reaction buffer, PCR nucleotide mix and nuclease-free water added to oligo $(\mathrm{dT})_{15}$, and random primers $(0.5 \mu \mathrm{g} /$ reaction $)$. RNA in the reverse transcription mixture was denatured at $70^{\circ} \mathrm{C}$ for $5 \mathrm{~min}$ and then annealed at $25^{\circ} \mathrm{C}$ for $5 \mathrm{~min}$. First strand synthesis occurred at $42^{\circ} \mathrm{C}$ for $60 \mathrm{~min}$, and RT was inactivated at $70^{\circ} \mathrm{C}$ for $15 \mathrm{~min}$. Taqman ${ }^{\circledR}$ Universal PCR master mix and 40X Taqman ${ }^{\circledR}$ human megalin probe (rs_2229263) were used for the quantification of gene expression (Applied Biosystems ${ }^{\circledR}$, Green Island, NY).

Megalin mRNA expression was normalized to that of $18 \mathrm{~S}$ (reference gene) which was measured using the Taqman ${ }^{\circledR}$ gene expression assay (Hs99999901_s1). PCR reactions were performed using the Bio-Rad C1000 Thermal Cycler ${ }^{\circledR}$ and the Bio-Rad C1000 Manager software ${ }^{\circledR}$ (Bio-Rad®, Hercules, CA). mRNA was expressed as the normalized expression ratio as described by Livak et al. (20) Briefly, this method uses the number of cycles at which the fluorescence signal is detected $(\mathrm{Ct})$ to quantify gene expression. It normalizes the expression of the target gene (megalin) to that of a reference gene (18S) and a calibrator sample (arbitrary sample that is designated as a control). The resulting ratio is multiplied by $100 \%$ to show percentage.

\section{Megalin Activity in BeWo Cells}

Given that albumin is an endogenous substrate of megalin, the time and temperature dependence of fluorescein-labeled BSA was evaluated to confirm the functional activity of megalin in BeWo cells. Cells were incubated with 10 and $100 \mu \mathrm{g} / \mathrm{mL}$ of FITC-BSA in Dulbecco's phosphate buffered saline (DPBS) (fluorescein/protein molar ratio of 7:1; Sigma Aldrich, St. Louis, MO). A 1000-fold excess of the unlabeled BSA (i.e., $10 \mathrm{mg}$ and $100 \mathrm{mg} / \mathrm{L}$ of BSA) was also added to the incubation solution to prevent the nonspecific binding of FITC-BSA. The reaction was stopped by washing the cells four times with ice-cold DBPS, and cellular content was assessed by treating the cells with Nonidet P40 lysis buffer (NP-40 buffer: $150 \mathrm{mM} \mathrm{NaCl}, 1 \% \mathrm{NP}-40$ and $50 \mathrm{mM}$ Tris-HCl; $\mathrm{pH}=8$ ) on ice for $30 \mathrm{~min}$. The fluorescein lysate was then measured using the Synergy $2 \circledR$ microplate reader (BioTek® US, Winooski, VT) at excitation $485 \mathrm{~nm}$, emission $520 \mathrm{~nm}$, and uptake was normalized to protein content which was determined using the BCA protein assay kit.

The cellular content of FITC-BSA was evaluated at 2, 5, 15, 30, and $60 \mathrm{~min}$. Uptake of $100 \mu \mathrm{g} / \mathrm{ml}$ of FITC-BSA was also measured at $4{ }^{\circ} \mathrm{C}$ and in the presence of gentamicin $(2 \mathrm{mM})$. Cells were pre-incubated with gentamicin for $20 \mathrm{~min}$, and uptake was measured after $15 \mathrm{~min}$ of gentamicin and BSA co-incubation. Uptake of FITC-BSA was also measured in the presence of 2 and $4 \mathrm{mg} / \mathrm{ml}$ of sodium maleate, an agent known to cause shedding of the megalin protein (10). Cells were pre-incubated with 2 and $4 \mathrm{mg} / \mathrm{ml}$ of sodium maleate for $3 \mathrm{~h}$ and were subsequently incubated with FITC-BSA for $15 \mathrm{~min}$. A calibration curve of fluorescence $v s$. BSA concentration $(\mu \mathrm{g} / \mathrm{ml})$ was constructed to calculate cellular contents of BSA in microgram. Uptake was then normalized to the protein content of cells (mg).

\section{Evaluation of Gentamicin Uptake and the Effect of Megalin Inhibitors}

In order to assess the effect of time and temperature on gentamicin uptake, labeled ${ }^{3} \mathrm{H}$-gentamicin $(200 \mathrm{mCi} / \mathrm{g}$; $0.5 \mu \mathrm{M}$; American Radiolabeled Chemicals, Saint Louis, MO) and unlabeled $2 \mathrm{mM}$ gentamicin in $1 \mathrm{ml}$ of DPBS (Research Products International Corp., Mount Prospect, IL) were added to the cells. The reaction was stopped by washing the cells three times with ice-cold DPBS. Cells were lysed for 30 min on ice with NP-40 lysis buffer, and samples were subsequently drawn for analysis by liquid scintillation counting (LSC). Uptake was normalized to protein content, which was measured using the BCA protein assay kit. Gentamicin uptake was measured at 2, 5, 10, 20, 40, and $60 \mathrm{~min}$ to assess time dependence. The effect of temperature was assessed by examining the uptake of gentamicin at 37 and $4^{\circ} \mathrm{C}$. Saturation studies were performed by exposing the cell to a fixed concentration of the labeled gentamicin (i.e., 100,000 disintegrations per minute $(\mathrm{DPM}) / \mathrm{ml}$ ) as well as to the following increasing concentrations of unlabeled gentamicin: $0.125,0.25,0.5,1,2,4$, and $6 \mathrm{mM}$. For all ${ }^{3} \mathrm{H}-$ gentamicin analyses, DPM values were converted to molar mass units.

Gentamicin uptake was also studied in the presence of inhibitors known to interfere with the megalin endocytic pathway (EDTA, (21) cytochalasin D (22)), compete with gentamicin binding to the megalin receptor (RAP) (24), or cause shedding of megalin from the cells where it is expressed (sodium maleate) (10). BeWo cells were incubated with RAP (1 $\mu \mathrm{M})$, EDTA $(10 \mathrm{mM})$, and cytochalasin D $(5 \mu \mathrm{g} / \mathrm{ml}$; $\sim 10 \mu \mathrm{M}$ ) for $30 \mathrm{~min}$. Cells were also pre-incubated with 2 and $4 \mathrm{mg} / \mathrm{ml}$ of sodium maleate $(\mathrm{pH}=7.4)$ for $3 \mathrm{~h}$. Inhibitors were added to both the apical and basolateral chambers. When the inhibitor was not soluble in DPBS, such as is the case of cytochalsin $\mathrm{D}, 0.2 \% \mathrm{v} / \mathrm{v}$ of dimethyl sulfoxide (DMSO) was added to the control and test cells, and then cells were incubated with gentamicin \pm the inhibitor for $10 \mathrm{~min}$. 


\section{Statistical Analysis}

The significance of differences observed between data means for gentamicin uptake as a function of time was assessed one-way analysis of variance (ANOVA) followed by Tukey's post hoc test for multiple comparisons. Effects of temperature and inhibitors on ${ }^{3} \mathrm{H}$-gentamicin were analyzed by Student's $t$ test (two groups) or ANOVA ( $>2$ groups). Concentration dependency of gentamicin uptake was fit to the MichaelisMenten equation. All statistical analyses were performed using GraphPad® Prism 6 (GraphPad Software, Inc., La Jolla, CA). The level of significance for all analyses was $\alpha=0.05$. Unless otherwise indicated, data are presented as mean \pm SD.

\section{RESULTS}

Megalin Expression and Activity. Immunoblot analysis of BeWo cells grown on uncoated Transwell plates demonstrated the presence of a distinct band at a molecular weight greater than $225 \mathrm{kDa}$. This band was also present in the positive control (rat kidney, Fig. 1).
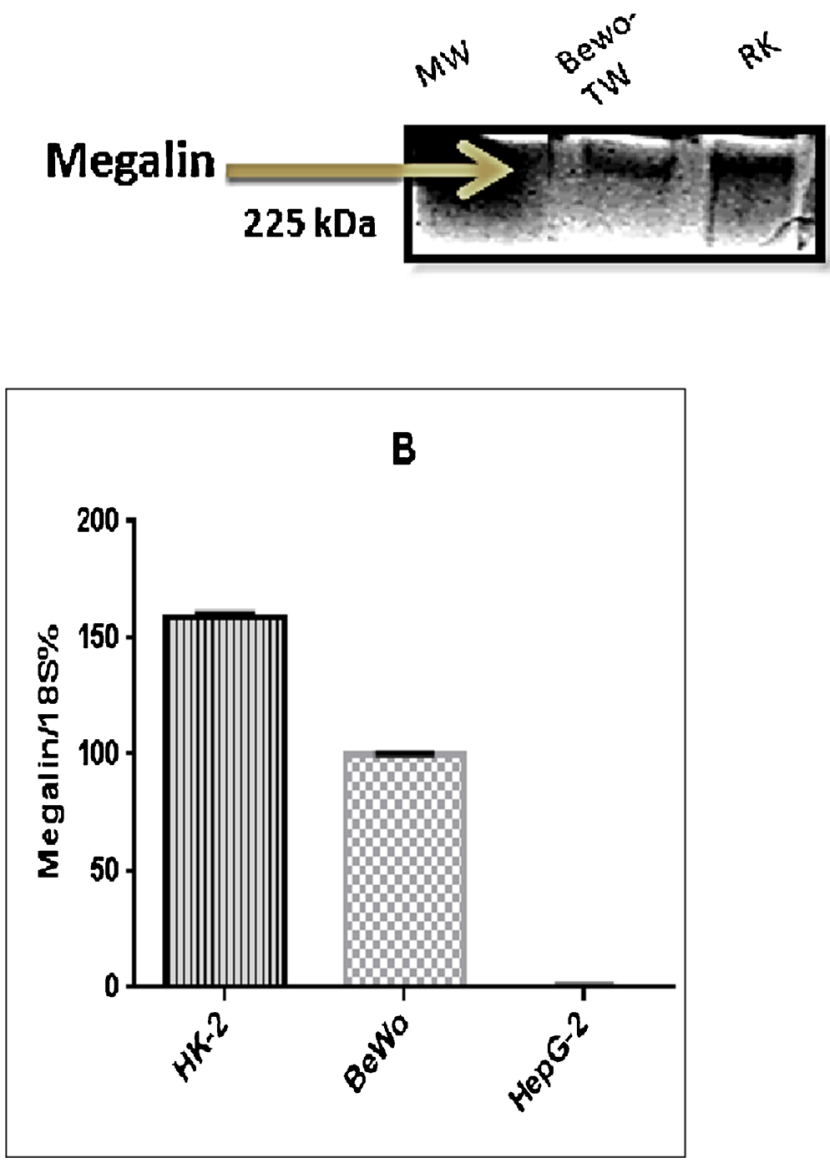

Fig. 1. Megalin mRNA expression in human kidney type 2 (HK-2), BeWo, and human hepatocellular carcinoma cells (HepG-2). Expression is expressed as the normalized ratio multiplied by $100 \%$ (data represent mean \pm SD of $n=3$ ). $* p<0.05$ for the statistical comparison of mRNA expression between HK-2 cells vs. BeWo and HepG2; † $p<0.05$ for the statistical comparison of mRNA expression of BeWo vs. HepG2. Figure insert: Immunoblots of megalin in BeWo cells grown on Transwell ${ }^{\circledR}$ plates. $M W$ molecular weight marker, $T W$ Transwell, $R K$ rat kidney)
qPCR analysis also demonstrated expression of megalin mRNA in BeWo cells and in the positive control (human kidney cells (HK-2) cells, Fig. 1b). Megalin mRNA expression in the positive control was significantly higher than in the BeWo cells and the negative control (HepG2 cells) $(p<0.05)$. In contrast, megalin mRNA expression was significantly higher in BeWo cells than in the negative control $(p<0.05)$.

In order to assess megalin activity in BeWo cells, the time, concentration, and temperature dependence of FITC-BSA, a megalin substrate, was evaluated. With respect to time and concentration dependence, uptake of $10 \mu \mathrm{g} / \mathrm{ml}$ FITC-BSA at $60 \mathrm{~min}$ was significantly higher than that at 2 and $5 \mathrm{~min}$ (Table I). Uptake of $100 \mu \mathrm{g} / \mathrm{ml}$ FITC-BSA was also time dependent and was significantly higher at $60 \mathrm{~min}$ than at 2 and $5 \mathrm{~min}$ (Table I). In addition, FITC-BSA uptake was greater at all time points with the $100 \mu \mathrm{g} / \mathrm{ml}$ concentration compared the $10 \mu \mathrm{g} / \mathrm{ml}$ concentration. Collectively, these data suggest a transporter mediated process that is consistent with the activity of megalin.

FITC-BSA uptake was also temperature dependent as evidenced by a significant reduction in uptake of the $100 \mu \mathrm{g} / \mathrm{ml}$ concentration at the 15 -min time point when evaluated at $4^{\circ} \mathrm{C}(15.5 \pm 2.3)$ compared to $37^{\circ} \mathrm{C}(83 \pm 18)$. Uptake was also significantly reduced $(50 \%, p<0.05)$ in the presence of $2 \mathrm{mM}$ of unlabeled gentamicin (Table II) and by 50 and $70 \%$ after incubation with 2 and $4 \mathrm{mg} / \mathrm{ml}$ of sodium maleate, respectively (Table II). These data are consistent with the time and concentration data and suggest that the megalin protein is functionally active in BeWo cells.

\section{Gentamicin Uptake and Effect of Megalin Inhibitors}

Uptake of ${ }^{3} \mathrm{H}$-gentamicin $(2 \mathrm{mM})$ at $37^{\circ} \mathrm{C}$ increased steeply from 2 to $20 \mathrm{~min}$ and subsequently began to level off (Fig. 2a). Uptake at 60, 40, and $20 \mathrm{~min}$ was significantly higher than that at 2, 5, and $10 \mathrm{~min}$ $(p<0.05)$. There was also a rise in gentamicin uptake as the concentration increased from 0.0625 to $2 \mathrm{mM}$ followed by a plateau until saturation was achieved at a concentration of $6 \mathrm{mM}$ (Fig. 2b). Michaelis-Menten fit of the data showed a $K_{\mathrm{m}}$ of 2.93 (SD $0.68 ; 95 \%$ CI $1.50-4.30$ ) $\mathrm{mM}$ and $V_{\max }$ of 42.3 (SD 4.90; 95\% CI 3.20-5.20) nmol

Table I. Uptake of 10 and $100 \mu \mathrm{g} / \mathrm{ml}$ of FITC-BSA in BeWo Cells at $2,5,15,30$, and $60 \mathrm{~min}$

\begin{tabular}{lcc}
\hline Time $(\mathrm{min})$ & $\begin{array}{c}\text { Uptake of } 10 \mu \mathrm{g} / \mathrm{ml} \\
(\mu \mathrm{g} / \mathrm{mg} \text { protein })\end{array}$ & $\begin{array}{c}\text { Uptake of } 100 \mu \mathrm{g} / \mathrm{ml} \\
(\mu \mathrm{g} / \mathrm{mg} \text { protein })\end{array}$ \\
\hline 2 & $3.5 \pm 0.5^{\dagger}$ & $40.9 \pm 6.1^{\dagger}$ \\
5 & $9.3 \pm 3.5^{\dagger}$ & $54.6 \pm 8.7^{\dagger}$ \\
15 & $14.6 \pm 1.9$ & $81 \pm 11$ \\
30 & $27.3 \pm 6.6$ & $103 \pm 15$ \\
60 & $33.8 \pm 6.9$ & $140 \pm 18$ \\
\hline
\end{tabular}

Data represent mean \pm SD $(n=3)$

${ }^{t} p<0.05$ between 60 -min time point and 2 and 5 min, respectively 
Table II. Uptake of $100 \mu \mathrm{g} / \mathrm{ml}$ of FITC-BSA at $4^{\circ} \mathrm{C}$, in the Presence of $2 \mathrm{mM}$ Gentamicin (Experiment 1) and Sodium Maleate (Experiment 2) at $15 \min \left(37^{\circ} \mathrm{C}\right)$

\begin{tabular}{|c|c|c|c|c|c|c|}
\hline Experiment & Control & $4^{\circ} \mathrm{C}$ & $\begin{array}{c}2 \mathrm{mM} \\
\text { gentamicin }\end{array}$ & $\begin{array}{c}2 \mathrm{mg} / \mathrm{ml} \text { of } \\
\text { sodium maleate }\end{array}$ & $\begin{array}{c}4 \mathrm{mg} / \mathrm{ml} \\
\text { sodium maleate }\end{array}$ & $\begin{array}{l}p \text { value (compared } \\
\text { to control) }\end{array}$ \\
\hline 1 & $83 \pm 18$ & $15.5 \pm 2.3$ & $41.5 \pm 7.4$ & & & $p<0.05$ \\
\hline 2 & $94 \pm 16$ & & & $45.6 \pm 6.3$ & $25.3 \pm 6.2$ & $p<0.05$ \\
\hline
\end{tabular}

Data represent mean $\pm \mathrm{SD}(n=6)$

gentamicin/mg protein/min. ${ }^{3} \mathrm{H}$-gentamicin uptake at the 10 -min time point was also significantly higher at $37^{\circ} \mathrm{C}$ than that at $4^{\circ} \mathrm{C}(17.8 \pm 2.4$ vs. $3.59 \pm 0.1 \mathrm{nmol}$ gentamicin/ mg protein).

Uptake of ${ }^{3} \mathrm{H}$-gentamicin at $37^{\circ} \mathrm{C}$ was evaluated in the presence of the following three megalin inhibitors: RAP, cytochalasin D, and EDTA. Uptake was also evaluated in the presence of maleate, a megalin shedding agent. Gentamicin uptake was decreased by approximately $70 \%$ in the presence of both RAP and EDTA $(p<0.05$, Table III). Cytochalasin D, an endocytosis inhibitor, also showed a trend toward
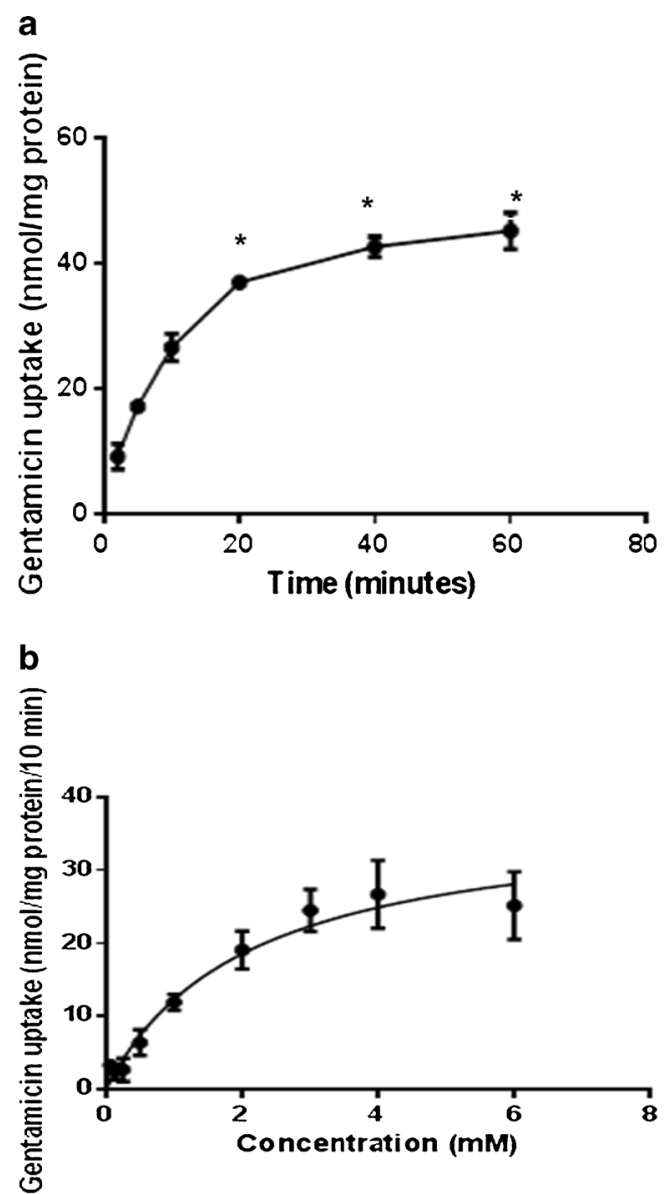

Fig. 2. a Time dependence of gentamicin $(2 \mathrm{mM})$ uptake in BeWo cells $(n=3)$. b Concentration dependence of gentamicin uptake BeWo cells (data represent mean $\pm \mathrm{SD} ; n=3-6$ ) decreased uptake (26\%) but did not reach statistical significance. In maleate-untreated cells (control group), gentamicin uptake in the positive control (MDCK cells) was significantly higher than that in BeWo cells. Uptake in both MDCK and BeWo cells was significantly $(p<0.05)$ higher than that in HepG2 cells (Table IV). Uptake of gentamicin in the positive control (MDCK cells) was significantly decreased by the addition of $2 \mathrm{mg} / \mathrm{ml}$ and $4 \mathrm{mg} / \mathrm{ml}$ of maleate $(p<0.05)$. Treatment with $2 \mathrm{mg} / \mathrm{ml}$ of maleate caused a drop in the uptake. Increasing the maleate concentration resulted in a significant decrease in gentamicin uptake relative to the control and to the $2 \mathrm{mg} / \mathrm{ml}$ dose (Table IV). In BeWo cells, uptake of gentamicin in the presence of $4 \mathrm{mg} / \mathrm{ml}$ of sodium maleate (Table IV) was significantly decreased by $45 \% \quad(p<0.05)$, while at $2 \mathrm{mg} / \mathrm{ml}$ uptake also showed a trend toward a decrease $(p>0.05)$. However, no effect of maleate treatment on the uptake of gentamicin in the HepG2 cells (negative control) was observed (Table IV).

\section{DISCUSSION}

In the current study, we demonstrated that megalin is expressed in BeWo cells grown in a three-dimensional environment (Transwell ${ }^{\circledR}$ cell-culture plates). Our data also strongly indicate that the megalin protein is active in this in vitro system. We demonstrated that the uptake of FITC labeled BSA (a known megalin substrate) (23) was time-, concentration-, and temperature-dependent, all of which suggest a transporter-mediated process. FITC-BSA uptake was also significantly reduced in the presence of unlabeled gentamicin (a megalin substrate) and sodium maleate (a megalin shedding agent) (10). Collectively, these data suggest that the megalin protein is functionally active in BeWo cells, and that this cell line is an appropriate in vitro model to study megalin-mediated placental transport.

This study is also the first to evaluate the mechanisms involved in placental AG uptake and provides initial evidence

Table III. The Effect of Megalin Inhibitors on the Uptake of ${ }^{3} \mathrm{H}$ gentamicin at $10 \mathrm{~min}$ in the BeWo Cells

\begin{tabular}{lccc}
\hline Control & $\begin{array}{c}\text { RAP } \\
(1 \mu \mathrm{M})\end{array}$ & $\begin{array}{c}\text { Cytochalasin D } \\
(5 \mu \mathrm{g} / \mathrm{ml})\end{array}$ & $\begin{array}{c}\text { EDTA } \\
(10 \mathrm{mM})\end{array}$ \\
\hline $27.5 \pm 5.5$ & $9.1 \pm 0.2^{*}$ & $20.2 \pm 4.0$ & $8.1 \pm 1.4^{*}$ \\
\hline
\end{tabular}

Data represent mean $\pm \mathrm{SD} ; n=3$

$* p<0.05$ 
Table IV. Effect of Sodium Maleate on the Uptake of Gentamicin in MDCK, BeWo, and HepG-2 Cells

\begin{tabular}{lccc}
\hline $\begin{array}{l}\text { Cell } \\
\text { type }\end{array}$ & Control & $\begin{array}{c}2 \mathrm{mg} / \mathrm{ml} \\
\text { sodium maleate }\end{array}$ & $\begin{array}{c}4 \mathrm{mg} / \mathrm{ml} \\
\text { sodium maleate }\end{array}$ \\
\hline MDCK & $64.8 \pm 3.0$ & $43.5 \pm 6.5$ & $33.5 \pm 5.6^{*}$ \\
BeWo & $24.6 \pm 5.0^{\S}$ & $20.4 \pm 2.7$ & $14.4 \pm 2.6 \dagger$ \\
HepG2 & $11.4 \pm 1.9^{\S}$ & $9.4 \pm 2.0$ & $11.1 \pm 0.6$ \\
\hline
\end{tabular}

Data represent mean $\pm \mathrm{SD}$

$M D C K$ Madin-Darby canine kidney epithelial cells

$\S p<0.05$ for the difference in gentamicin uptake between different cell lines; $* p<0.05$ for the effect of maleate on gentamicin uptake in MDCK cells; $\dagger p<0.05$ for the effect of maleate in BeWo cells; $n=6$ )

that megalin-mediated endocytosis is involved in placental AG transport. Using the BeWo cell model, we demonstrated that gentamicin uptake exhibited time and temperature dependence, saturability, and Michaelis-Menten kinetics, all of which are consistent with a protein-mediated transport process. Gentamicin uptake was also significantly reduced in the presence of the megalin inhibitors RAP and EDTA suggesting that megalin is likely involved in the uptake process. Our data are consistent with those from previous investigations, which demonstrated a $50 \%$ reduction in the amount of gentamicin accumulation in RAP-deficient kidneys (24) and an increase in gentamicin excretion in rat perfused proximal tubules in the presence of RAP (25). Sodium maleate, a megalin-shedding agent, also caused a significant decrease in gentamicin uptake $(30-45 \%)$ providing further evidence that megalin is involved in the uptake process. This decrease in uptake was accompanied by a simultaneous decrease in megalin protein expression by $50 \%$. These findings are consistent with those from a previous in vivo study by Nagai et al. (10), which showed that administration of intraperitoneal sodium maleate $(400 \mathrm{mg} / \mathrm{kg})$ decreased amikacin accumulation by $50 \%$ in the renal cortex of Wistar rats within $3 \mathrm{~h}$ after injection.

Interestingly, we observed that there was some gentamicin uptake in HepG2 cells, the negative control. This suggests that mechanisms other than megalin-mediated endocytosis may be involved in hepatic AG uptake. Since the liver is not a physiologic site of AG-induced toxicity or pharmacologic action, however, the uptake of AGs by hepatocytes has not been extensively studied and data are limited to a small number of studies in animal models which also show limited hepatic uptake after intravenous administration (25-27). Hepatocytes may therefore be a model that can be used to investigate non-megalin-mediated mechanisms of AG transport such as passive diffusion and organic cationic transport.

In our study, cells were incubated with gentamicin concentrations that are almost 1000 -fold higher than what the placenta would be exposed to in clinical settings $(8,12-$ 14). While these levels would seem clinically irrelevant, they provide a proof of concept. In addition, gentamicin exhibit nonspecific binding to various surfaces, so experiments dealing with its uptake should be high enough to saturate these sites. Our choice of incubation concentration ( $2 \mathrm{mM} \sim 1 \mathrm{mg} / \mathrm{ml}$ ) was based on the concentration dependence study. We obtained a $K_{\mathrm{m}}$ value of $2.93 \mathrm{mM}$, a value that is comparable to a previous study by Tauris et al. (28).
This study is limited to studying gentamicin uptake in an in vitro model of immortalized placental choriocarcinoma cell line (i.e., the BeWo cells). While this cell line provides a good in vitro model system to study the transcellular distribution of nutrients and drugs across the placental trophoblast (29), the uptake of gentamicin can be otherwise assessed by utilizing human placental trophoblasts. The latter are useful to study expression, localization, and functional activity of placenta. Trophoblast cultures can be prepared from term placentas; however, the primary trophoblast monolayers are difficult to use for transport studies. Instead of forming a tight-junctioned monolayer appropriate for transport studies, these nonproliferative, multinucleated cells form aggregates with large intercellular spaces when grown on semi-permeable membranes (30). This drawback was overcome by Hemmings et al. (31) who have prepared confluent cell layers of syncytiotrophoblasts on semi-permeable supports which function as an effective barrier to low and high molecular weight molecules (31).

Collectively, these data provide initial insight into the molecular mechanisms involved in the uptake and transport of AGs across human placenta. Since both megalin protein and mRNA are expressed in the BeWo cells grown on Transwell ${ }^{\circledR}$ plates, these cells appear to be a valid model to assess the role of megalin in AG uptake. Moreover, considering data from our functional studies, megalin-mediated endocytosis is at least partially involved in the binding and uptake of AGs by placenta and ultimately the fetal delivery of these antibiotics.

\section{ACKNOWLEDGMENTS}

The authors would like to thank Dr. Scott Walsh and Ms. Sonya Washington from the department of Obstetrics and Gynecology at VCU for their help obtaining the preterm placental samples. We would also like to thank Dr. Ken Audus for the gift of BeWo cells, and Dr. Matthew Beckman for samples of mouse kidney and liver from the VCU Massey Cancer Center Transgenic/Knock-out Mouse Facility, supported, in part, with funding from NIH-NCI Cancer Center Support Grant P30 CA016059.

We would also like to acknowledge funding from the Thomas F. and Kate Miller Jeffress Trust and the VCU School of Pharmacy. Additionally, Dr. Akour was supported by a scholarship from the University of Jordan.

\section{REFERENCES}

1. Riggs JW, Blanco JD. Pathophysiology, diagnosis, and management of intraamniotic infection. Semin Perinatol. 1998;22(4):251-9.

2. Fahey JO. Clinical management of intra-amniotic infection and chorioamnionitis: a review of the literature. J Midwifery Womens Health. 2008;53(3):227-35.

3. Tita AT, Andrews WW. Diagnosis and management of clinical chorioamnionitis. Clin Perinatol. 2010;37(2):339-54.

4. Hopkins L, Smaill F. Antibiotic regimens for management of intraamniotic infection. Cochrane Database Syst Rev. 2002;3, CD003254.

5. Wendel Jr GD, Leveno KJ, Sanchez PJ, Jackson GL, McIntire DD, Siegel JD. Prevention of neonatal group B streptococcal disease: a combined intrapartum and neonatal protocol. Am J Obstet Gynecol. 2002;186(4):618-26. 
6. Nahum GG, Uhl K, Kennedy DL. Antibiotic use in pregnancy and lactation: what is and is not known about teratogenic and toxic risks. Obstet Gynecol. 2006;107(5):1120-38.

7. Bernard B, Garcia-Cazares SJ, Ballard CA, Thrupp LD, Mathies AW, Wehrle PF. Tobramycin: maternal-fetal pharmacology. Antimicrob Agents Chemother. 1977;11(4):688-94.

8. Gilstrap 3rd LC, Bawdon RE, Burris J. Antibiotic concentration in maternal blood, cord blood, and placental membranes in chorioamnionitis. Obstet Gynecol. 1988;72(1):124-5.

9. Schentag JJ, Cerra FB, Plaut ME. Clinical and pharmacokinetic characteristics of aminoglycoside nephrotoxicity in 201 critically ill patients. Antimicrob Agents Chemother. 1982;21(5):721-6.

10. Nagai J, Tanaka H, Nakanishi N, Murakami T, Takano M. Role of megalin in renal handling of aminoglycosides. Am J Physiol Renal Physiol. 2001;281(2):F337-44.

11. Watanabe A, Nagai J, Adachi Y, Katsube T, Kitahara Y, Murakami T, et al. Targeted prevention of renal accumulation and toxicity of gentamicin by aminoglycoside binding receptor antagonists. J Control Release. 2004;95(3):423-33.

12. Yoshioka H, Monma T, Matsuda S. Placental transfer of gentamicin. J Pediatr. 1972;80(1):121-3.

13. Weinstein AJ, Gibbs RS, Gallagher M. Placental transfer of clindamycin and gentamicin in term pregnancy. Am J Obstet Gynecol. 1976;124(7):688-91.

14. Kauffman RE, Morris JA, Azarnoff DL. Placental transfer and fetal urinary excretion of gentamicin during constant rate maternal infusion. Pediatr Res. 1975;9(2):104-7.

15. Larsson M, Hjalm G, Sakwe AM, Engstrom A, Hoglund AS, Larsson E, et al. Selective interaction of megalin with postsynaptic density-95 (PSD-95)-like membrane-associated guanylate kinase (MAGUK) proteins. Biochem J. 2003;373 (Pt 2):381-91.

16. Nielsen R, Birn H, Moestrup SK, Nielsen M, Verroust P, Christensen EI. Characterization of a kidney proximal tubule cell line, LLC-PK1, expressing endocytotic active megalin. J Am Soc Nephrol. 1998;9(10):1767-76.

17. Servais H, Jossin Y, Van Bambeke F, Tulkens PM, MingeotLeclercq MP. Gentamicin causes apoptosis at low concentrations in renal LLC-PK1 cells subjected to electroporation. Antimicrob Agents Chemother. 2006;50(4):1213-21.

18. Hao Q, Hong SH, Maret W. Lipid raft-dependent endocytosis of metallothionein in HepG2 cells. J Cell Physiol. 2007;21((2):428-35.
19. Takeda T, Yamazaki H, Farquhar MG. Identification of an apical sorting determinant in the cytoplasmic tail of megalin. Am J Physiol Cell Physiol. 2003;284(5):C1105-13.

20. Livak KJ, Schmittgen TD. Analysis of relative gene expression data using real-time quantitative PCR and the 2(-Delta Delta C(T)) Method. Methods. 2001;25(4):402-8.

21. Moestrup SK, Birn H, Fischer PB, Petersen CM, Verroust PJ, Sim RB, et al. Megalin-mediated endocytosis of transcobalamin-vitamin-B12 complexes suggests a role of the receptor in vitamin-B12 homeostasis. Proc Natl Acad Sci U S A. 1996;93(16):8612-7.

22. Decorti G, Malusa N, Furlan G, Candussio L, Klugmann FB. Endocytosis of gentamicin in a proximal tubular renal cell line. Life Sci. 1999;65(11):1115-24.

23. Zhai XY, Nielsen R, Birn H, Drumm K, Mildenberger S, Freudinger R, et al. Cubilin- and megalin-mediated uptake of albumin in cultured proximal tubule cells of opossum kidney. Kidney Int. 2000;58(4):1523-33.

24. Moestrup SK, Cui S, Vorum H, Bregengard C, Bjorn SE, Norris K, et al. Evidence that epithelial glycoprotein 330/megalin mediates uptake of polybasic drugs. J Clin Invest. 1995;96(3):1404-13.

25. Prabakaran T, Nielsen R, Larsen JV, Sorensen SS, FeldtRasmussen U, Saleem MA, et al. Receptor-mediated endocytosis of alpha-galactosidase A in human podocytes in Fabry disease. PLoS One. 2011;6(9), e25065.

26. Tran Ba Huy P, Bernard P, Schacht J. Kinetics of gentamicin uptake and release in the rat. Comparison of inner ear tissues and fluids with other organs. J Clin Invest. 1986;77((5):1492-500.

27. Kornguth ML, Kunin CM. Distribution of gentamicin and amikacin in rabbit tissues. Antimicrob Agents Chemother. 1977;11(6):974-7.

28. Tauris J, Christensen EI, Nykjaer A, Jacobsen C, Petersen CM, Ovesen T. Cubilin and megalin co-localize in the neonatal inner ear. Audiol Neurootol. 2009;14(4):267-78.

29. Liu F, Soares MJ, Audus KL, Liu F, Soares MJ, Audus KL. Permeability properties of monolayers of the human trophoblast cell line BeWo. Am J Physiol. 1997;42:C1596-604.

30. Bode CJ, Jin H, Rytting E, Silverstein PS, Young AM, Audus KL. In vitro models for studying trophoblast transcellular transport. Methods Mol Med. 2006;122:225-39.

31. Hemmings DG, Lowen B, Sherburne R, Sawicki G, Guilbert LJ. Villous trophoblasts cultured on semi-permeable membranes form an effective barrier to the passage of high and low molecular weight particles. Placenta. 2001;22:70-9. 